KREA-TIF: JURNAL TEKNIK INFORMATIKA

http://ejournal.uika-bogor.ac.id/krea-tif

p-ISSN: 2338-2910

Vol 5, No. 2, Oktober 2017, pp. 86-96

DOI : 10.32832/kreatif.v5i2.2188

\title{
Membangun Website E-Commerce Menggunakan Framework Codeigniter Pada Chemistry Merch
}

\author{
Robi Maulana, R. Fitria Rachmawati * \\ Program Studi Teknik Informatika, Akademi Teknologi Bogor, Indonesia \\ *e-mail koresponden: fitria@uika-bogor.ac.id
}

\begin{abstract}
Abstrak
Sistem promosi yang kurang serta jangkauan yang terbatas dalam pemasaran barang menyebabkan omset toko menjadi tidak tercapai. Penerapan e-Commerce merupakan teknologi yang sanagt mendukung dalam penjualan produk dikarenakan berbasis internet sehingga dapat menjangkau tanpa batas. Website e-commerce Chemistry Merch menjadikan sarana media promosi serta penjualan produk. Metode pengembangan sistem pada penelitian ini berbasis waterfall yang dimana pada tahapan awal melakukan studi literature untuk mencari solusi permasalah serta sistem kerja website e-commerce. Perancangan website serta implementasi merupakan tahapan lanjut dalam pembuatan sistem. Penelitian ini membuat website e-commerce dengan menggunakan bahasa pemograman PHP Codeigniter yang dikombinasikan dengan database MySql. Pemesanan melalui website ini dapat menghemat waktu dan biaya dibandingkan dengan pemesanan secara langsung datang ke store, dan pembeli dapat melihat katalog produk yang dapat langsung dilihat di halaman website ini.
\end{abstract}

Kata kunci: Website , E-Commerce, Codeigniter.

\begin{abstract}
Promotional systems that are lacking as well as a limited reach in marketing goods cause store turnover to be unreachable. The application of e-Commerce is a technology that is very supportive in selling products due to internet-based so that it can reach without limits. The ecommerce Chemistry Merch website makes it a medium for promotional media and product sales. The system development method in this study is waterfall based, which at the initial stage conducted a literature study to find problem solutions and work systems for e-commerce websites. Website design and implementation are further stages in making the system. This research makes e-commerce website using PHP Codeigniter programming language combined with MySql database. Ordering through this website can save time and costs compared to ordering directly come to the store, and buyers can see the product catalog that can be directly viewed on this website page..
\end{abstract}

Keywords: Website , E-Commerce, Codeigniter.

\section{PENDAHULUAN}

E-commerce atau bisa disebut perdagangan elektronik atau e-dagang adalah penyebaran, pembelian, penjualan, pemasaran barang dan jasa melalui internet atau jaringan komputer. Seluruh komponen yang ada dalam perdagangan diaplikasikan ke dalam $e$ commerce seperti customer service, layanan produk, cara pembayaran dan cara promosi. Perkembangan internet yang semakin maju merupakan salah satu faktor pendorong berkembangnya e-commerce. Internet merupakan salah satu jaringan global yang 
menghubungkan jaringan komputer diseluruh dunia, sehingga memungkinkan terjalinnya komunikasi dan interaksi antar satu perusahaan dengan konsumen.

Chemistry Merch merupakan perusahaan distribution outlet atau yang biasa disebut distro merupakan konsep usaha ritel yang menyediakan berbagai pakaian casual, jaket, celana dan pakaian-pakaian. Umumnya usaha dengan konsep distro lebih mengutamakan kebutuhuan untuk anak-anak muda dan mahasiswa. Sistem penjualan yang digunakan di Chemistry Merch saat ini masih menggunakan fasilitas traditional seller dan sosial media seller karena belum memiliki e-commerce sehingga penjualan belum maksimal. Dalam pencatatan transaksi penjualan Chemistry Merch masih secara manual, sehingga sering teerjadi kesalahan dalam pembuatan laporan. Dengan menggunakan fasilitas sosial media sebagai sarana penjualan maka lingkup penjualan dan promosi pun masih belum maksimal. Solusi yang diajukan untuk mengatasi masalah Chemistry Merch untuk mengembangkan bisnis penjualan nya yaitu e-commerce.

Berdasarkan uraian latar belakang, Chemistry Merch memerlukan suatu sarana atau layanan penjualan berbasis website (e-commerce) yang bisa memenuhi kebutuhan dan bisa memudahkan perusahaan dalam menjalankan kegiatan bisnis seperti penjualan, pembelian, promosi produk baru, pembayaran dan transaksi jarak jauh, sehingga perusahaan bisa memperluas wilayah pemasarannya. Dari penelitian ini penulis membuat judul "Membangun Website e-Commerce Menggunakan Framework Codeigniter Pada Chemistry Merch".

Untuk membangun sebuah website dibutuhkan sebuah framework, yang dapat membantu pembangunan dan pengembangan website itu sendiri sehingga developer tidak perlu membangun sebuah website dari awal lagi jika ingin memperbarui fitur-fitur pada website yang sudah ada sehingga sumberdaya yang dibutuhkan tidak terlalu banyak [2]. Codeingniter adalah sebuah framework PHP yang dapat mempercepat pengembang untuk membuat sebuah aplikasi web[3]. Keuntungan penggunaan framework adalah: menghemat waktu pengembangan, reuse code, bantuan komunitas dan kumpulan best practices [3]. Pembuatan web e-commerce menggunakan framework codeigniter dengan tahapan identifikasi masalah melalui analisis kebutuhan, membuat perancangam kemudian mengimplementasikannya serta melakukan pengujian [4]. Salah satu contohnya adalah pembuatan Barca-CMS dengan framework CodeIgniter yang menggunakan arsitektur Model-View-Control, di mana dasar arsitekturnya adalah adalah pemisahan logika aplikasi dengan tampilan. Ternyata pola ini dapat meminimalisir penulisan perintah, sehingga resiko terjadinya bug juga minimal, serta meningkatkan efisiensi pembangunan aplikasi [5].

Dari permasalahan di atas Chemistry Merch belum mempunyai sarana untuk mempromosikan produk secara digital karena masih menggunakan brosur, belum adanya penyimpanan data yang terstruktur dan tidak adanya layanan transaksi penjualan jarak jauh yang bisa mempermudah dalam memperluas wilayah pemasaran.

Adapun tujuan dibuatnya website e-commerce menggunakan framework codeigniter pada Chemistry Merch ini adalah untuk membantu dan mempermudah perusahaan dalam penyebarluasan informasi dan promosi produk melalui pembangunan website e-commerce pada Chemistry Merch.

\section{METODE PENELITIAN}

Metode perancangan sistem yang digunakan adalah waterfall. Berdasarkan SDLC Waterfall Model adalah sebagai berikut:

\section{a. Perencanaan}

Pada tahap ini langkah-langkah yang perlu dilakukan adalah mengidentifikasi masalah dengan analisa kelemahan sistem dan preliminary investigation.

\section{Membangun Website E-Commerce Menggunakan Framework Codeigniter Pada Chemistry Merch}




\section{b. Analisis}

Pada tahap ini hasil yang didapatkan pada perencanaan dianalisis apa saja yang menjadi penyebabnya. Setelah mengetahui penyebab permasalahan berikutnya yang dilakukan adalah menentukan metode yang cocok digunakan untuk menyelesaikan permasalahan. Dalam tahapan ini terdiri dari 3 bagian yaitu:

a. Requirement Model.

b. Data dan Process Model menggunakan DFD dan flow diagram.

c. Development Strategies.

\section{c. Desain}

Tahapan desain merupakan spesifikasi sistem yang dirancang secara lengkap yang dibuat berdasarkan kebutuhan yang telah direkomendasikan pada tahapan sebelumnya. Pada tahapan ini langkah-langkahnya adalah sebagai berikut:

a. Perancangan database sistem meliputi:

- Menentukan entitas dan atribut database.

- Relasi dan Normalisasi Tabel.

- Physical System.

b. Desain Antar Muka/ User Interface Design.

c. Desain Algoritma Proses Sistem.

\section{d. Implementasi}

Tahap implementasi merupakan tahapan menerapkan semua hasil desain pada tahap sebelumnya dibuat dalam bentuk prototype website. Pada perancangan website ini pengkodean dilakukan dengan bahasa pemrograman PHP dan MySQL sedangkan untuk hosting dilakukan dengan program Xampp.

\section{e. Pengujian}

Proses pengujian terdiri atas verifikasi dan validasi dan uji prototype [1]

- Verifikasi adalah pengujian apakah program sudah menerjemahkan model konseptual menjadi sistem computer yang dilakukan secara benar.

- Validasi adalah pengujian apakah program sudah mempresentasikan tujuan perancangan sudah sesuai dengan kebutuhan pengguna.

- Uji Prototype ditujukan untuk membandingkan antara sistem lama dengan sistem baru yang dirancang.

\section{HASIL DAN PEMBAHASAN}

\section{a. Perancangan Arsitektur Yang Diusulkan}

Pelanggan yang ingin membeli produk tidak harus lagi datang ke store atau office untuk bertemu dengan bagian pemasaran ataupun melakukan pemesanan barang melalui telepon ke bagian pemasaran, tapi sudah lebih mudah untuk melakukan pemesanan barang berikut rincian prosedur yang diusulkan diantaranya :

a. Prosedur Pelanggan/Member

Prosedur yang diusulkan pada pelanggan yang sudah dapat diakses kapan dan dimana saja untuk melakukan order barang yang sudah tidak lagi harus datang ke store maupun ke office.

b. Prosedur Pemasaran

Prosedur yang diusulkan untuk pemasaran produk tidak lagi menggunakan media cetak 
seperti brosur, melainkan dapat langsung melihat katalog produk dengan menggunakan media internet.

c. Prosedur Pengiriman

Prosedur yang diusulkan pada pengiriman, yaitu menerima data pesanan dan konfirmasi pembayaran yang masuk dari pelanggan. Kemudian pelanggan hanya menunggu datangnya kiriman barang sampai ditempat.

d. Prosedur Owner

Prosedur yang diusulkan pada owner untuk mengecek laporan transaksi penjualan, stok barang masuk, hanya melalui halaman owner.

e. Prosedur Admin

Prosedur yang diusulkan pada admin untuk mengupdate berita, event, stokbaang dan kegiatan hanya melalui halaman admin.

f. Prosedur Operator

Prosedur yang diusulkan pada operator untuk mengecek transaksi penjualan dan semua kegiatan terkait produk hanya melalui halaman operator.

\section{b. Use Case Diagram}

Use case adalah gambaran graphical dari beberapa atau semua actor, use case, dan interaksi diantaranya yang memperkenalkan suatu sistem. Use case diagram tidak menjelaskan secara detail tentang penggunaan use case, tetapi hanya memberi gambaran singkat hubungan antara use case, aktor, dan siste .Didalam use case ini akan diketahui fungsi - fungsi apa saja yang berada pada sistem yang dibuat.

\section{Use Case Diagram pelanggan}

Use case diagram pelanggan (Gambar 1) menggambarkan interaksi atau dialog antara sistem dan user, termasuk petukaran pesan dan tindakan yang dilakukan oleh sistem dan user.

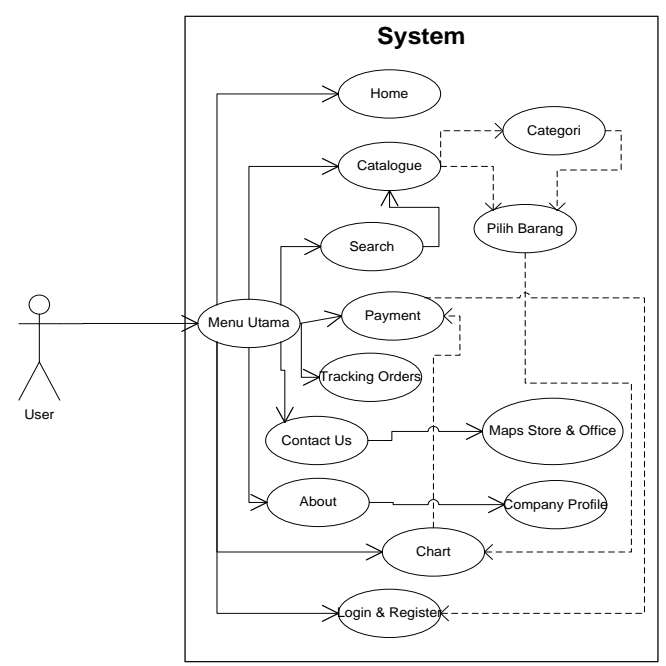

\section{Gambar 1. Use Case Diagram Pelanggan}

Usecase Diagram Pelanggan pada Gambar 1 terdapat :

a) Sistem yang mencakup seluruh kegiatan sistem informasi penjualan barang pada Chemistry Merch

b) Actor yaitu pelanggan yang melakukan kegiatan transaksi.

c) Use Case yang dilakukan oleh actor pelanggan tersebut diantaranya : view barang, pilih barang, registrasi, order barang, konfirmasi pesanan, transfer pembayaran dan konfirmasi pembayaran. 
d) Include untuk login dan konfirmasi pembayaran.

\section{Use Case Diagram Manajemen e-Commerce}

Use case diagram manajemen menggambarkan interaksi atau dialog antara sistem dan actor, termasuk petukaran pesan dan tindakan yang dilakukan oleh sistem.

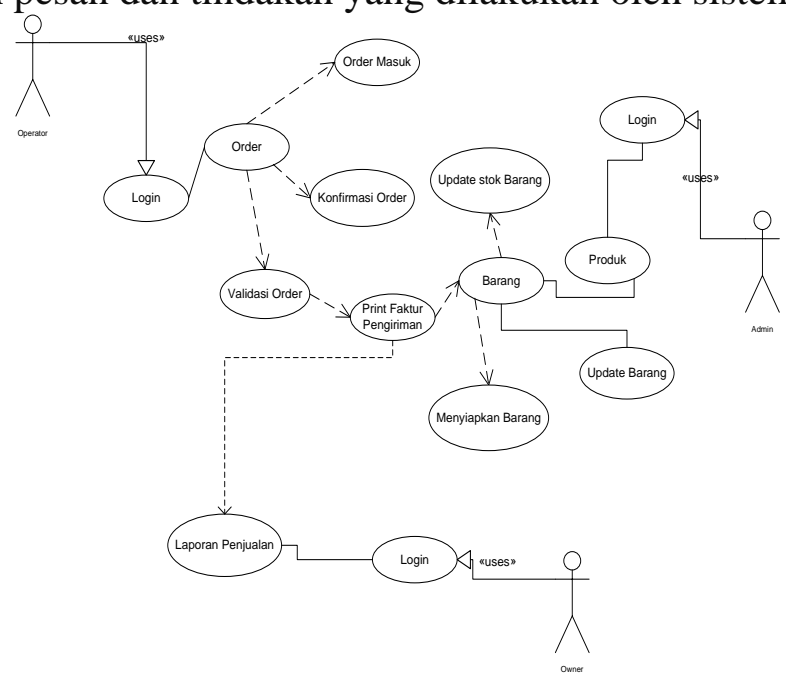

\section{Gambar 2. Use Case Diagram Manajemen E-commerce Chemistry Merch}

Use Case Diagram Manajemen pada Gambar 2 terdapat :

a) Sistem yang mencakup seluruh kegiatan sistem informasi penjualan barang pada Chemistry Merch

b) Aktor yaitu operator yang melakukan kegiatan validasi order, admin yang melakukan kegiatan update barang dan stok, owner yang melihat laporan kegiatan penjualan.

c) Use Case yang dilakukan oleh actor operator tersebut diantaranya : view order, order masuk, konfirmasi order, validasi order, print faktur, dan menyiapkan barang.

d) Use Case yang dilakukan oleh aktor admin tersebut diantaranya : view barang, stok barang, update barang, menyiapkan barang. Use Case yang dilakukan oleh aktor owner tersebut diantaranya : melihat laporan dari kegiatan transaksi.

\section{c. Diagram Konteks}

Diagram Konteks pada tahap perancangan penelitian ini dapat dilihat pada Gambar 3.

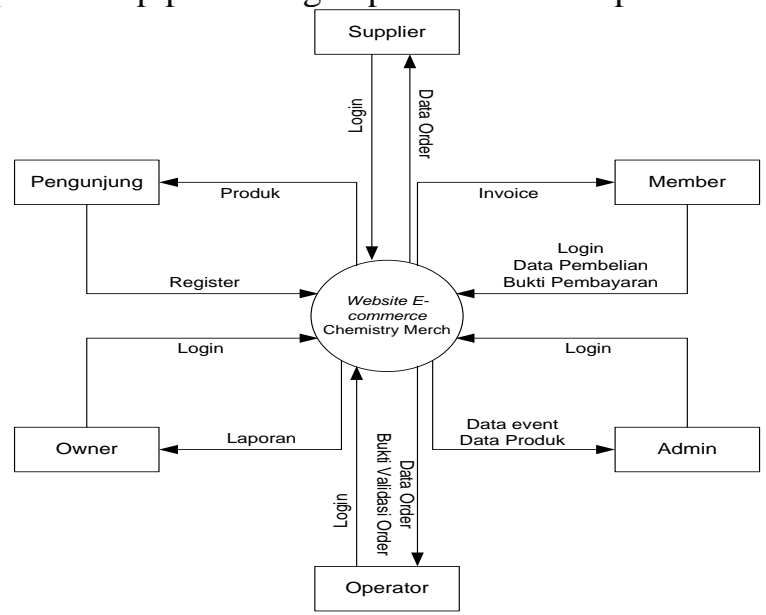

Gambar 3. Diagram Konteks 


\section{Data Flow Diagram Level 1 Proses 1 Daftar Member}

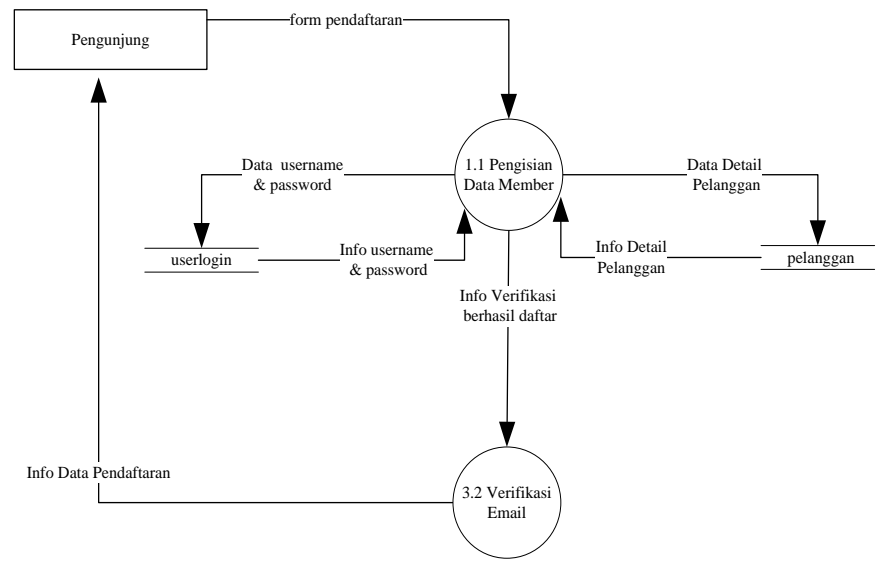

\section{Gambar 4. DFD Level 1 Proses 1 Daftar Member}

Proses-proses yang terjadi pada Daftar Member (Gambar 4) adalah sebagai berikut :

1. Pengisian data daftar member

Proses awal yang harus dilakukan oleh seorang calon member adalah melakukan pengisian data daftar member. Kemudian data daftar member yang telah diinputkan akan disimpan pada tabel member

2. Verifikasi email

Setelah daftar member diinputkan maka sistem akan melakukan proses verifikasi email.

\section{Data Flow Diagram Level 1 Proses 2 Login}

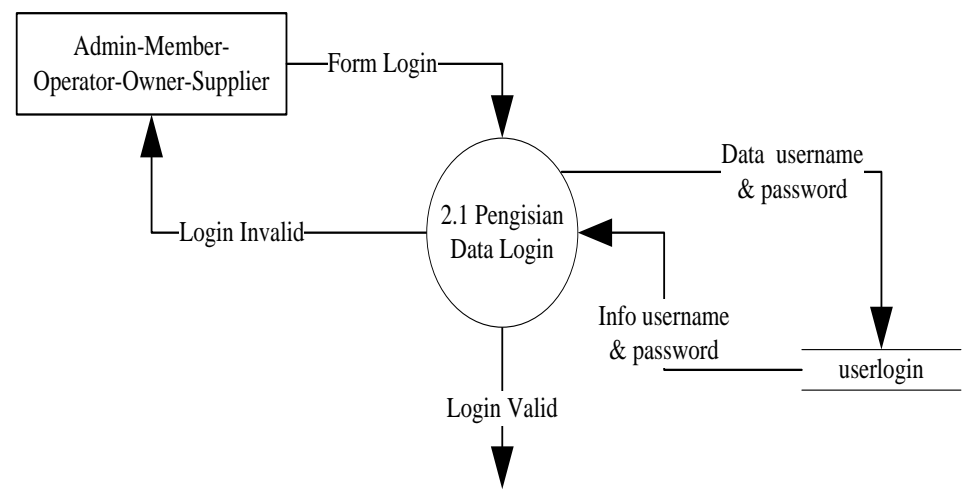

Gambar 5. DFD Level 1 Proses 2 Login

Proses-proses Gambar 5 yang terjadi pada Pengolahan Data sebagai berikut :

\section{Input username}

Merupakan proses untuk melakukan penginputan username admin, member, owner, operator dan supplier kemudian sistem akan melakukan proses pengecekan data 
username

2. Input password

Merupakan proses untuk melakukan penginputan password admin, member, owner, operator dan supplier kemudian sistem akan melakukan proses pengecekan data password admin.

\section{Data Flow Diagram Level 1 Proses 5 Pengolahan Data Order}

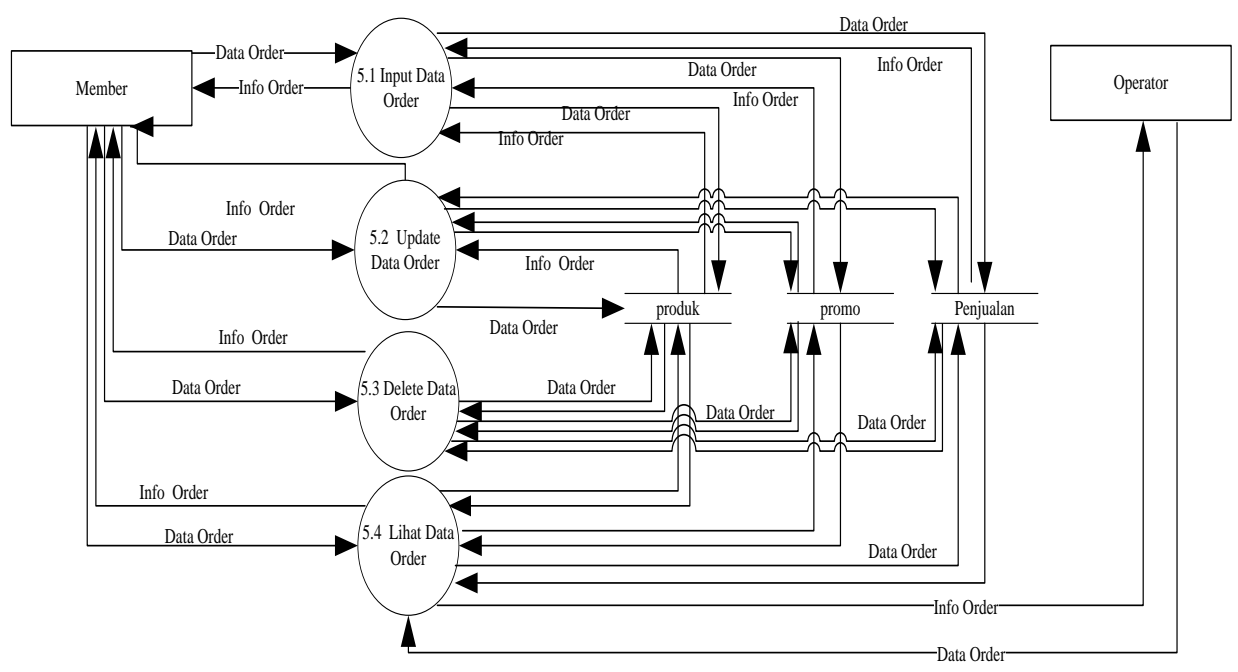

\section{Gambar 6. DFD Level 1 Proses 5 Pengolahan Data Order}

Proses-proses Gambar 6 yang terjadi pada Pengolahan Data Pesanan adalah sebagai berikut :

1. Input Data Pesanan

Proses ini melakukan pengelolaan data pesanan yang diinputkan oleh member dan menyimpannya dalam tabel penjualan

2. Edit Data Pesanan

Proses ini akan melakukan pengeditan data pesanan jika sewaktu-waktu ada kesalahan dalam penginputan data pesanan

3. Delete Data Pesanan

Proses ini akan melakukan penghapusan data pesanan yang tidak jadi dipesan.

4. Lihat Data Detail Pesanan

Proses ini akan menampilkan semua data pesanan member

\section{d. Implementasi}

Pengujian system usulan dilakukan untuk mengetahui berhasil atau tidaknya suatu program yang dirancang sesuai kebutuhan. Pengujian dilakukan dengan metode penginputan data. Penginputan data memfokuskan pada keperluan fungsional dari program. kemudian ketikkan alamat "http://localhost/chemistry/" pada address bar. Setelah loading selesai, maka akan muncul tampilan yang dapat dilihat pada Gambar 7 hingga Gambar 16

a. Tampilan Halaman Utama 


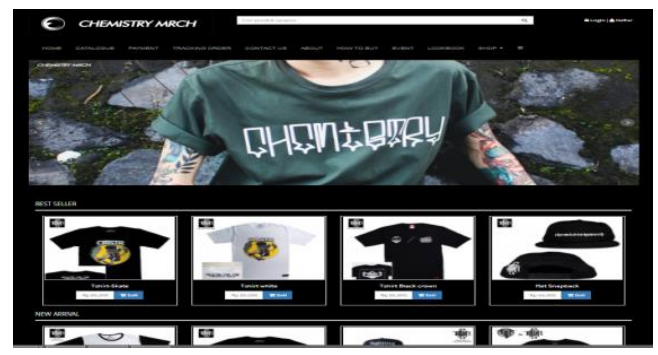

Gambar 7. Halaman Utama

b. Tampilan Catalogue

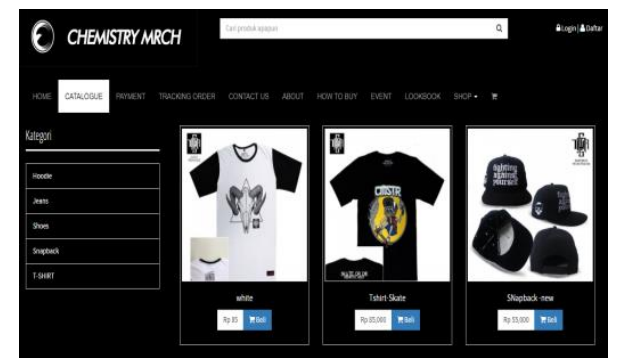

Gambar 8. Catalogue

c. Tampilan Tracking Order

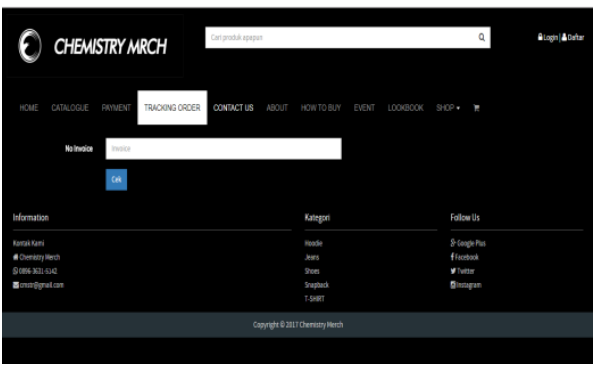

Gambar 9. Tracking Order

d. Tampilan Payment

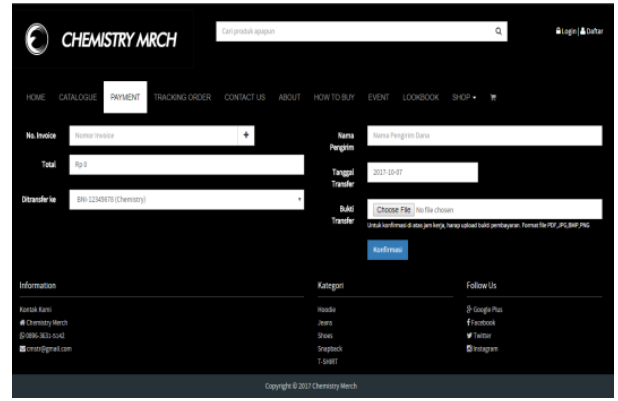

Gambar 10. Payment

e. Tampilan About 


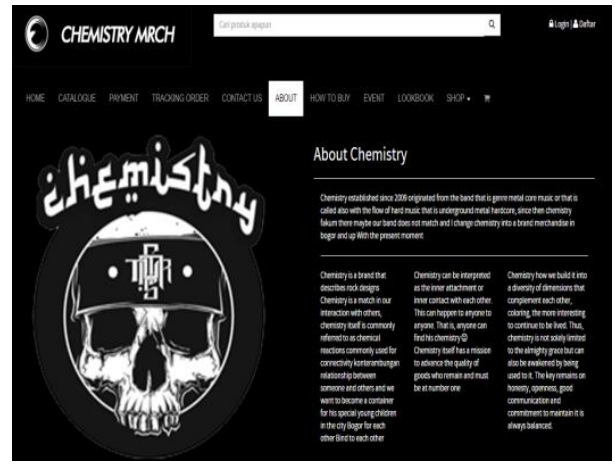

Gambar 11. About

f. Tampilan How To Buy

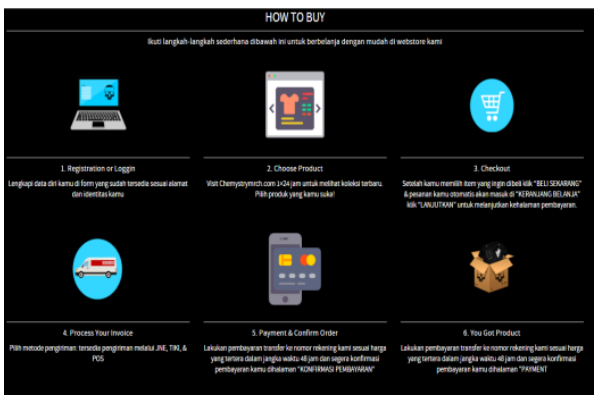

Gambar 12. How To Buy

g. Tampilan Contact Us

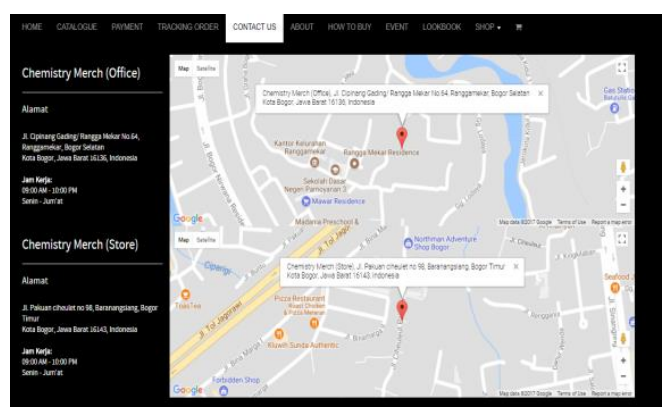

Gambar 13. Contact Us

h. Tampilan Beli

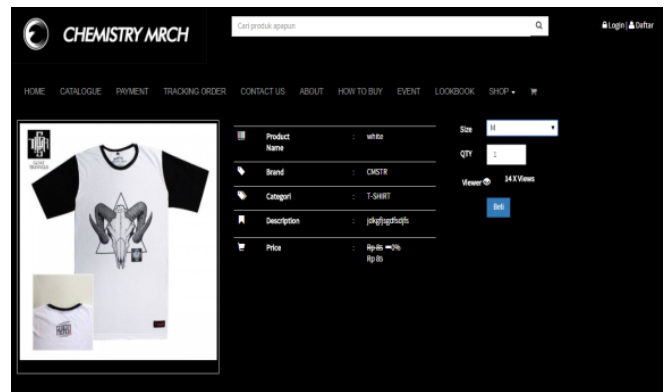

Gambar 14. Beli

i. Tampilan Shopping Chart 


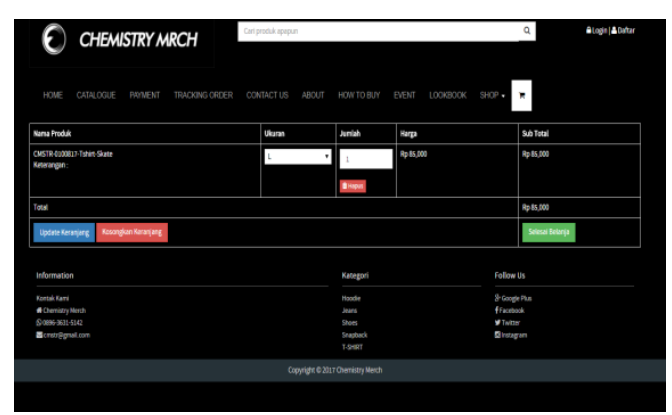

Gambar 15. Shopping Chart

j. Tampilan Konfirmasi

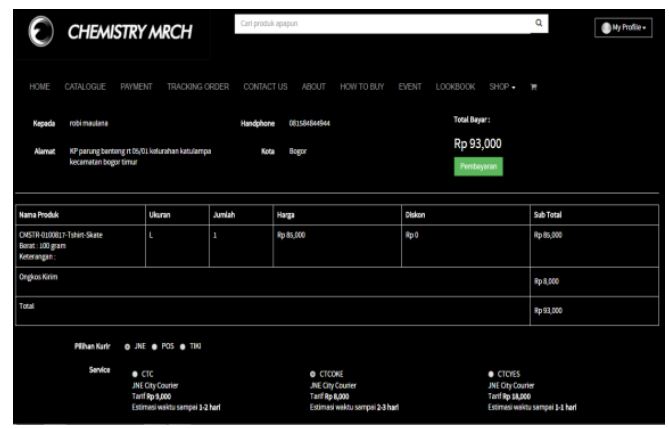

Gambar 16. Konfirmasi

\section{e. Hasil Pengujian}

Tabel 3.1 Hasil Pengujian

\begin{tabular}{ll}
\hline \multicolumn{1}{c}{ Halaman Website } & Keterangan \\
\hline Halaman Utama & Bisa diakses \\
Halaman Catalogue & Bisa diakses \\
Halaman Tracking & Bisa diakses \\
Halaman Payment & Bisa diakses \\
Halaman About & Bisa diakses \\
Halaman HTB & Bisa diakses \\
Halaman Contact Us & Bisa diakses \\
Halaman Beli & Bisa diakses \\
Halaman Chart & Bisa diakses \\
Halaman Konfirmasi & Bisa diakses \\
\hline
\end{tabular}

\section{KESIMPULAN}

Berdasarkan hasil dan pembahasan maka dapat dambil kesimpulan sebagai berikut :

1) Website E-Commerce Chemistry Merch adalah sebuah sistem penjualan online yang baru dibentuk untuk bisa bersaing di dunia E-Commerce. Sistem Website E-Commerce Chemistry dapat diakses dimana saja dan kapan saja selama masih terkoneksi dengan jaringan internet. Pengoptimalan untuk sistem Website E-Commerce Chemistry masih selalu dalam tahap penyampurnaan.

2) Website E-Commerce Chemistry sudah menggunakan konsep E-Commerce B2B (Business To Business ) yang merupakan metode untuk mempermudah transaksi online pada Chemistry Merch. Dengan begitu sistem transaksi menjadi lebih efektif dan efisien.

\section{DAFTAR PUSTAKA}

[1] Pressman S Roger. Software Engineering: A Practitioner's Approach, Seventh 
Edition (2010). Published by McGraw-Hill. New York. USA.

[2] Ruli Erinton, Ridha Muldina Negara, Danu Dwi Sanjoyo. Analisis Performasi Framework Codeigniter dan Laravel Menggunakan Web Server Apache. ISSN : 2355-9365 e-Proceeding of Engineering : Vol.4, No.3 Desember 2017 | Page 3565. Prodi S1 Teknik Telekomunikasi, Fakultas Teknik Elektro, Universitas Telkom, Bandung

[3] Ibnu Daqiqil. Framework Codeigniter-Sebuah Panduan dan Best Practices. www.koder.web.id. Kumpulan tutorial komputer. 2011.

[4] Putu Tri Sabdojati, Amir Fatah Sofyan. Pembuatan Web E-Commerce Menggunakan Framework Codeigniter untuk Menjangan Abadi Kartasura. (2016). Teknik Informatika STMIK Amikom Yogyakarta

[5] Shalahuddin Salim Tsani. Perancangan dan Pembuatan Content Managemen System (Cms) "Barca Cms" Menggunakan Framework Codeigniter. 2013. Jurusan Teknik Informatika, Universitas Muhammadiyah Surakarta

[6] Arief, M.Rudianto. Pemrograman Web Dinamis Menggunakan Php dan Mysql. ANDI, Yogyakarta, 2011.

[7] Fariz Zakal Alam. Analisis dan Perancangan Toko Online Kaos Bola Distro Holly Moly. Naskah Publikasi, Sekolah Tinggi Manajemen Informatika Dan Komputer Amikom Yogyakarta, Yogyakarta, 2013.

[8] Fendy Tay. Analisis dan Perancangan WebsiteDengan Menggunakan analisis Tows (Studi Kasus Toko BodhiPro. Naskah Publikasi, Sekolah Tinggi Manajemen Informatika Dan Komputer Amikom Yogyakarta, Yogyakarta, 2014.

[9] Hakim, Lukmanul. Bikin Website Super Keren Dengan PHP \& Jquery. Lokomedia, Yogyakarta, 2010.

[10] Lia Setiawan. Pembuatan Website E-commerce Butik Diar Lutfi Surakarta. Tugas Akhir, Teknik Informatika, Fakultas Matematika dan Ilmu Pengetahuan Alam, Universitas Sebelas Maret, Surakarta, 2009.

[11] Muhamad Bagir. Pembuatan Website E-commerce Di PT Batik Rahmawati Surakarta. Tugas Akhir, Teknik Informatika, Fakultas Matematika dan Ilmu Pengetahuan Alam, Universitas Sebelas Maret, Surakarta, 2011.

[12] Pahlevy, Randy, Tesar. Rancang Bangun Sistem pendukung Keputusan Menentukan penerima Beasiswa dengan Menggunakan metode Simpele Additive Weighting (SAW).

Skripsi Program Studi Tehnik Informatika. Universitas Pembangunan Nasional "Veteran", Surabaya, 2010.

[13] Viktor Nicolas Nore. Perancangan Sistem Informasi Penjualan Dan Pemesanan Produk Berbasis Web (Studi Kasus Di CV. Richness Development Bandung). Tugas Akhir, Sistem Informasi, Fakultas Teknik, Universitas Widyatama Bandung, Bandung, 2013. 